\title{
Walking the Walk: Gender-bland Sexism, The Fan Experience and Perceptions of Value in Women's Professional Cricket
}

\author{
Keith D. Parry, Jessica Richards, Jo Batey \& Aila Khan
}

\section{Introduction}

Historically, sport has been the domain of males and is often perceived as a site for reinforcing traditional ideas about masculinity (Muir et al., 2020). Sporting images and language often glorify heroic manhood with women confined mainly to the roles of "spectator, supporter, and admirer" (Osborne \& Coombs, 2013, p.673). When sports celebrate masculinity, gender ideology defines women as invaders (Coakley et al., 2011) and men's sport continues to be seen as the 'standard' to judge sport in terms of status. As a result, women's versions of sports are often gender marked as the 'other' version. For instance, and pertinently for this chapter, the men's professional Twenty20 (T20) cricket competition in Australia is referred to as the BBL (Big Bash League) while the women's version is known as the WBBL (Women's Big Bash League).

Against this cultural backdrop, women's sport in Australia has undergone rapid expansion recently. In 2016 the Australian women's rugby union team won gold at the Olympics in Rio, whilst in 2017, the Australian association football team (the 'Matildas') won the Tournament of Nations, and the first national Australian rules football league for women (the AFLW) was launched. A new national women's rugby league competition (the NRLW) followed in 2018. These new opportunities for professional women athletes to play sports for financial reimbursement were in addition to the already established professional women's netball and association football leagues. The rise in women's professional competitions has proved attractive to sports fans in Australia and is creating lucrative markets for various sporting codes. This can be illustrated by large sell-out crowds for the Matildas, and the attendance figures at the 2019 grand final of the AFLW, where a crowd of over 53,000 was recorded (Gaskin, 2019). However, while we refer to these leagues as 'professional', in that the players are rewarded for their performances, many of the conditions that they operate within are far removed from those of professional men's sport. Players are frequently poorly remunerated via short-term contracts and are provided with inferior playing conditions. Until recently it has been challenging for women to make a professional full-time career from these sports.

In 2015, a women's professional T20 cricket competition was introduced. Despite being governed by Cricket Australia, the WBBL initially had low public awareness and limited commercial appeal, 
reflective of the organisation's attitude towards women's cricket more widely (Stronach \& Adair, 2009). Nevertheless, involvement by women and girls is rising (Mooney et al., 2019) and recently there has been increased investment in (and public awareness of) women's cricket with the WBBL now attracting the leading international players. Highlighting this investment, payments to women professional cricketers rose from AU\$7.5million to AU\$55.2million in 2017 with minimum retainers for participating in the WBBL rising to AU\$11,584 by 2022, a move described as "the biggest pay rise in the history of women's sport" in Australia (Mooney et al., 2019, p.71). It remains to be seen whether these increases have been matched by similar levels of investment in the promotion and presentation of women's cricket, which are considered significant factors that shape perceptions of sport and influence motivations to attend matches (Trail \& Kim, 2011). This is despite the expansion of female sports leagues in Australia coinciding with both an increase in fans of women's sport and an increase in female fans at professional sporting events internationally, culminating in 86,174 fans attending the Women's T20 World Cup final between Australia and India at the Melbourne Cricket Ground on 8th March 2020 - International Women's Day (Pape, 2020). Clubs have seen growth in their fan bases and profits (Tailgate Sports Marketing, 2016). The increase in female fans across a range of sports challenges the notion that fans are a homogenous group consisting primarily of white, heterosexual adult men "bonding together through drinking beer" (McKay el al., 2009, p.173) while supporting male sports. Nevertheless, media coverage and marketing of sport remains focussed on male versions (Fink, 2015; Clarkson et al., 2020). Therefore, the overall aim of this research was to investigate the differences in the fan experience and the resultant perceptions of value at men's and women's T20 cricket matches.

\section{Cricket in Australia}

To understand the positioning of women's cricket in Australia we first provide an overview of cricket culture within Australia. On-field displays of masculine playing prowess in cricket have long been accompanied by corresponding off-field displays, particularly in terms of drinking excessive amounts of alcohol. While some ardent cricket fans claim that supporter groups are inclusive, regardless of "class, 'race', age, gender and regional loyalty" the more prominent groups, such as England's Barmy Army, continued to bear a closer resemblance to male drinking clubs that exhibit traditional forms of masculinity (Parry \& Malcolm, 2004, p.78).

As Wedgwood (1997) describes, crowds at men's cricket matches in Australia in the late 1990s celebrated and exhibited hegemonic masculine displays through behaviours such as streaking onto 
the playing field and denigrating women. Crowds at men's Test matches in Australia continue to be masculine dominated (Rowe, 2017) but the shortest form of the men's game, T20 cricket has attracted younger audiences and, significantly, more females (Axford \& Huggins, 2011). Yet, changes in the types of fans attending cricket in Australia remains underexplored (Wade, 2019).

\section{Importance of the fan experience}

Men's sport can appear favoured by broadcasters due to its higher profile and greater television presence (Shaw \& Amis, 2001). Although a number of factors influence a person's decision to attend a live sporting event, one which has been examined in some detail is that of the stadium itself, with both the physical environment and less tangible elements found to be important. For instance, perceptions of service quality at a venue will impact on a non-avid spectator's satisfaction and influence re-patronage intentions (Parry et al., 2018). Additionally, perceptions of the quality of the service at the stadium may also influence the intensity of the relationship formed between a fan and the sport club (Phonthanukitithaworn \& Sellitto, 2018). Therefore, there has been a considerable shift in the ways sporting organisations are engaging with fans on match-day at live sporting fixtures.

With steady declines in live sporting attendance (Parry et al., 2017) and an increasingly price-sensitive fan base, clubs and venues are engaging in relationship management with their fans. Hall et al. (2010) note that sport event expenditure has been declining as a percentage of total recreational expenditure. For this reason, clubs are investing in creating memorable fan experiences at games by offering additional services and entertainment products. These relationship management activities, known as fan engagement, can subsequently be transformed into increased profit for the organisation (Bradley, 2013). In practical terms, fan engagement can take a variety of forms such as; communication via email or social media; exclusive experiences, e.g. meet the players; game-day activations such as merchandise giveaways; stadium entertainment and on-field competitions. Evidence of this engagement can be witnessed in the promotional literature from the team that forms our case study, the Sydney Sixers. They described themselves as, "the rockstars of the Big Bash" who would "put on one of the best shows in town over the summer school holidays, with fireworks, music and fun over three hours of entertainment" (Sydney Sixers, 2018).

However, whether these changes and investment in match-day has also been applied to the product of the women's version of the game is less known. Despite increased investment in women's sport in recent years, the motivation for clubs and venues to enhance the fan experience seems to vary, with more resources being ploughed into targeting the engagement of fans watching men's cricket than women's cricket. However, when fan engagement is present in women's sport it is often 'family 
friendly', aimed at a heteronormative family target audience (Fielding-Lloyd, et al., 2020). While inequity of resourcing of men's versus women's sport has been explored from a range of perspectives, particularly the televising of games (Caple, et al., 2011; Lusted \& Fielding-Lloyd, 2017; Musto et al., 2017), there is limited research on the differences in resourcing for actual gameday presentation (see Allison, 2018). It is this gap in our understanding that this study seeks to fill.

To theorise our research, we build on the work of Musto et al. (2017) and their concept of "genderbland sexism", which they identify from a longitudinal study of sport media. Whereas media coverage of female sport has shifted from earlier overt sexism, through a state of ambivalence to a "pretty and powerful" discourse more recently (Bruce, 2016), Musto, et al. $(2017$, p.578) suggest that sports commentators and broadcasters currently "render women athletes visible in ways that makes women's athletic accomplishments appear lacklustre compared to men's". This diminishing is often done through the use of "bland" language that normalises the hierarchal dominance of male sport and reinforces gender boundaries while being able to avoid charges of overt sexism. Therefore, to extend our understanding of the prevalence of gender-bland sexism, we apply this concept to the resourcing and presentation of matches and examine if and how blandness can extend beyond media communications.

\section{Methodology}

This study used a mixed-methods approach, adopting an Exploratory Sequential Design (Creswell, 2013). The problem was first explored through initial qualitative participant observation, which then informed the development of an online survey. Sports fandom has largely been researched and understood through the interpretation of quantitative data (Parry et al., 2014) despite longstanding calls for more mixed methods research in this domain (Jones, 1997). This research aimed to move away from the traditional postpositivist worldview to embrace more constructivist and pragmatic philosophies, thus allowing us to explore the multiple norms, values, and meanings shared by sports fans through examining real-world practice.

\section{Participant Observation}

Participant observation was undertaken at two venues, the Sydney Cricket Ground (SCG) and the Hurstville Oval. The SCG is a large, historic venue steeped in cricket tradition located near the Central Business District (CBD) of Sydney. In contrast, Hurstville Oval is less centrally located, being approximately 20 kilometres from the CBD. There is seating for 1,000 in a small, covered grandstand with grass banks offering additional, informal spaces for spectators. While the Sixers BBL team primarily play at the SCG, WBBL games were split between the SCG and a number of less symbolic 
suburban venues. During the period of study, it was not uncommon for women's games at the SCG to precede the men's matches, with entry to the former provided as a free addition for those who purchased a ticket to a BBL game (starting at AU\$20 for an adult). When WBBL games were standalone offerings, admission was free.

The objective of the participant observation was to understand how cricket fans experience WBBL match-days at the SCG and the Hurstville Oval. The same researcher collected fieldwork data at four WBBL matches throughout January 2018. Two were held at the SCG (followed by a BBL game), and two were held at the Hurstville Oval. The first two matches held at the SCG each generated approximately eight hours of observational data since they included the men's matches that followed the women's matches. These observations allowed the researcher to note differences in fan engagement at women's and men's games at the same venue. The observations at the Hurstville Oval generated approximately four hours of data per match, as only the women's matches took place. Observations took place at various locations in and around the ground including the 'fan zones' outside the. Data was thematically analysed using the process introduced by Miles, et al. (2014). This involved creating codes developed from the data, and then thematically organising these codes and presenting evidence from the raw data.

\section{Survey Participants}

The survey was emailed to a database of Sixers members (season ticket or limited-game ticket holders) and generated 308 responses; females 52\% $(n=160)$ and males $48 \%(n=148)$. Participants' modal age was 18-24 years old. When asked where they had last attended a Sixers WBBL game, the most common venue was the SCG $(46 \%, n=139)$ followed by Hurstville Oval $(24 \%, n=72)$. Fifty-seven respondents (19\%) had not attended a Sixers WBBL game. Conversely, $34 \%$ of participants $(n=94)$ only attended WBBL games and the majority of participants were not regular attendees at BBL games, with $67 \%(n=187)$ attending 2 or fewer home games on average in a season.

\section{Measures}

The survey instrument contained five sections, examining both WBBL and BBL games. The initial section collected fan demographics and the following section asked about participants' knowledge of WBBL players. The third section of the survey focussed on consumption patterns and motivations, asking which venue the participants had most recently attended a Sixers WBBL home game and then examined the factors that influenced their decision to attend. This question was adapted from the Sport Fan Motivation Scale (Wann, 1995). The fourth section examined purchase intentions and the 
valuation of WBBL games. By using a 5-point Likert-type scale measured from much less to much more, we explored whether participants saw the same value in WBBL games played at suburban venues as at the SCG. Next, the likelihood that participants would purchase tickets to a WBBL game was measured using another 5-point Likert-type scale. Participants were then asked to identify what they considered to be a reasonable price for a general admission ticket to a WBBL match. The section finished by asking respondents to identify the matchday activations that they wanted to see at WBBL games.

\section{Results}

\section{Creating a Memorable Match-day}

The fan experience starts before the actual game begins (Parry, 2012) and at both venues' various promotional activities from sponsors and partners (often called activations) - a common feature of professional, commercialised sport - were present. For example, the area in the immediate vicinity of the SCG was lined with magenta banners (the Sixers' colour) bearing the club's logo alongside a variety of activations linked to cricket or the club's sponsors. It was noticeable that a number of these engagement points specifically advocated women's sport and many provided activities for children as evidence of the desire to target families. Inside the venue were fewer spaces for activations, but the walls of the concourses were decorated with images of the leading BBL players. Activations for children were primarily in the restricted access members area although giveaways of 'clap banners', inflatable hands, and 'KFC bucket head' hats (provided by the competition sponsor, KFC) were accessible for all spectators entering the venue. Additionally, although a variety of on-field fan engagement activities took place these only occurred during the BBL game. There were no fan engagement activities in the long interval between the women's and men's games. Fan activations observed during BBL games at the SCG also utilised video screens to display live fan interviews, encourage participation through 'snog'/'wiggle'/jump cams, and social media photo promotions. There were numerous, ad hoc activations encouraging the use of the free 'clappers', crowd cheers, and on-field sponsor-backed competitions. There were fewer of these during the WBBL games.

Music was used to entertain the crowd at the SCG games and to complement the ground announcements and game updates (for the incoming batter and score updates). Music was also used to fill 'dead' space when there was a lull in on-field action. For BBL games, the music was a mixture of chart hits and cult Australian favourites. At WBBL games, the music was predominantly by female artists and many of the song selections emphasised strong and independent women (such as Sisters are Doin' It For Themselves by Eurythmics and Run the World (Girls) by Beyoncé). This finding, 
however, stands in contrast to Hurstville Oval, with a smaller number of songs by female artists repeated several times.

The crowd sizes for the 'double-headers' were considerably smaller at the WBBL games (approximately 1,000) than the following BBL ones (over 22,000 at each game) with most spectators only arriving shortly before the men's game started. It should be noted that the WBBL games at the SCG were on a weekday, starting mid-afternoon (with the men's games starting in the evening when more people had finished work). The large capacity of the stadium meant that the ground felt largely empty during the women's games. Conversely, the aforementioned smaller playing area at Hurstville meant that fans were closer to the players and there were more occasions when balls were hit into the stands, providing more opportunities for spectators to join in the action by taking catches.

There were noticeable differences in the behaviour of fans at the BBL and WBBL games at the SCG. In the BBL matches, fans would often direct comments towards players, and the video screens replayed fielding errors or the wickets of opposition players to mock them further - typical behaviour at men's sport in Australia (Richards, et al., 2020). Verbal abuse or 'sledging' of players was less frequent during WBBL games in keeping with the family-oriented atmosphere found at women's sport (Fielding-Lloyd, et al., 2020). For instance, at Hurstville, spectators were quick to challenge a disparaging comment from a male spectator on the standard of women's cricket. Players of both teams were more frequently encouraged and congratulated for their performances with positive clapping and cheering.

During games, it was observed that the WBBL players were more focussed on the on-field action and interacted with the crowds less than their male counterparts. Male players engaged with spectators on a more regular basis by, for instance, signing autographs when they were close to the playing boundary. However, it should also be noted that although male players gave more interviews during play, this can also be linked to the greater opportunities afforded by the larger media teams that covered the BBL matches. The marketing of the games also contributed towards the atmosphere. For example, the men's games were portrayed as a battle between rivals; a titanic struggle. Women's games were marketed as cheap and enjoyable family days out, with a welcoming atmosphere that encouraged spectators to support women's cricket and to be a part of the wider cricket community, as Fielding-Lloyd, et al. (2020) found in their analysis of women's football. These findings provide evidence that gender-bland sexism can and does also exist in marketing and presentation of women's cricket, indicating that the normalisation of the hierarchal dominance of male sport occurs in various, often subtle ways. 


\section{Survey Findings}

The majority of participants from the survey (86\%) indicated that they would be likely to purchase tickets for Sixers WBBL games if an entry fee was introduced (Table 1). However, the survey indicated that females were significantly more likely than males to purchase tickets $\left[X^{2}(4, N=276)=7.895 ; p<\right.$ 0.1]. This relationship may be linked to traditional views on women's sport (Meier, 2015) and the ongoing need for female athlete role models. Additionally, this could also reflect that female fans are more likely to support women's sport.

Table 1. What is the likelihood that you would buy a ticket for WBBL games if an entry fee was introduced?

\begin{tabular}{|l|c|c|}
\hline & Percentage & Frequency \\
\hline Extremely likely & $54.95 \%$ & 161 \\
\hline Somewhat likely & $30.72 \%$ & 90 \\
\hline Neither likely nor unlikely & $8.87 \%$ & 26 \\
\hline Somewhat unlikely & $3.75 \%$ & 11 \\
\hline Extremely unlikely & $1.71 \%$ & 5 \\
\hline
\end{tabular}

Survey results demonstrated that there were differences in the financial valuation of women's and men's games. Participants were asked what they believed to be a reasonable price for a general admission ticket to a WBBL game (see Table 2). Answers ranged from a minimum of AU\$1.10 to AU\$40 with a mean value of AU\$17.58 (SD = 7.64). Results indicate gender differences in price perceptions (Independent Samples $t=.002, p=.01$ ) with the mean price that females were willing to pay (AU\$18.92) significantly higher than males (AU\$16.02). Participants were also asked to value a ticket to a BBL match. The mean value was AU\$20.21 (SD = 7.38). In this instance, there was no significant gender difference in how the BBL game was valued, and the figure reported matched the price for a general admission ticket at that time. However, this figure is higher than for the WBBL matches, showing that both male and female participants place higher financial value on the men's game.

Table 2. Perceptions of a reasonable ticket price for WBBL and BBL games

\begin{tabular}{|c|c|c|c|c|}
\hline & \multicolumn{2}{|c|}{ WBBL } & \multicolumn{2}{c|}{ BBL } \\
\hline Value & Percentage & Frequency & Percentage & Frequency \\
\hline
\end{tabular}




\begin{tabular}{|c|c|c|c|c|}
\hline$\$ 0.01-\$ 5.00$ & 2.9 & 9 & .6 & 2 \\
\hline$\$ 5.01-\$ 10.00$ & 11.3 & 35 & .3 & 1 \\
\hline$\$ 10.01-\$ 15.00$ & 18.4 & 57 & 3.5 & 11 \\
\hline$\$ 15.01-\$ 20.00$ & 30.0 & 93 & 10.3 & 32 \\
\hline$\$ 20.01-\$ 25.00$ & 17.4 & 54 & 29.7 & 92 \\
\hline$\$ 25.01-\$ 30.00$ & 7.1 & 22 & 21.6 & 67 \\
\hline$\$ 30.01-\$ 35.00$ & 3.5 & 11 & 11.0 & 34 \\
\hline$\$ 35.01-\$ 40.00$ & 3.2 & 10 & 5.5 & 17 \\
\hline
\end{tabular}

There was a significant relationship $\left(x^{2}=.067 p=.06\right)$ between gender and the valuation of the venue that Sixers WBBL games are held at (Table 3). Males placed less financial value on both BBL and WBBL games at suburban venues, such as the Hurstville Oval, than females did. These results suggest that smaller venues, which can be more intimate and family-friendly, appeal more to females and can also help to deepen their engagement with cricket.

Table 3. Do participants value suburban ground matches as much as those at the SCG?

\begin{tabular}{|l|c|c|c|c|}
\hline & \multicolumn{2}{|c|}{ WBBL } & \multicolumn{2}{c|}{ BBL } \\
\hline & Percentage & Frequency & Percentage & Frequency \\
\hline Much less & $6.48 \%$ & 19 & $11.11 \%$ & 30 \\
\hline Somewhat less & $13.65 \%$ & 40 & $17.78 \%$ & 48 \\
\hline About the same & $46.76 \%$ & 137 & $50.37 \%$ & 136 \\
\hline Somewhat more & $16.72 \%$ & 49 & $11.85 \%$ & 32 \\
\hline Much more & $16.38 \%$ & 48 & $8.89 \%$ & 24 \\
\hline
\end{tabular}

When asked what influenced their decision to attend Sixers WBBL games (Table 4), the most popular reasons given by participants were the love of cricket, supporting women's sport, entertainment, team loyalty, and to have fun. Interestingly, a number of respondents alluded to the importance of female role models for their children, and specifically their daughters via the 'other' option for this question. When asked the same question for BBL matches, a similar pattern emerged with the most common answers: love of cricket, team loyalty, entertainment, and to have fun. Of the responses listed as 'other', the double-header with the WBBL game was a common theme, as was the significance of 
matches at the SCG - a number of respondents noted that they held memberships at the stadium, which provided them with access to these matches.

Interestingly, the analysis revealed statistically significant patterns between respondents' gender and factors influencing the audience's decision to attend Sixers WBBL games. Females were more likely to attend a game to support women's sport and 'to socialise' and 'to have fun'. This finding supports research by Wann \& Waddill (2003) who describes how female fans were more likely to view sport spectating as an opportunity to spend time with friends and family.

Table 4. Factors influencing the decision to attend games

\begin{tabular}{|l|c|c|c|c|}
\hline & \multicolumn{2}{|c|}{ WBBL } & \multicolumn{2}{c|}{ BBL } \\
\hline Influence & Percentage & Frequency & Percentage & Frequency \\
\hline Love of cricket & $19.67 \%$ & 179 & $24.47 \%$ & 207 \\
\hline Supporting women's sport & $17.80 \%$ & 162 & & \\
\hline Entertainment & $12.75 \%$ & 116 & $15.25 \%$ & 129 \\
\hline Team loyalty & $12.09 \%$ & 110 & $16.08 \%$ & 136 \\
\hline To have fun & $11.65 \%$ & 106 & $13.36 \%$ & 113 \\
\hline Value for money & $9.67 \%$ & 88 & $11.23 \%$ & 95 \\
\hline Socialising (family, friends or teammates) & $8.90 \%$ & 81 & $11.70 \%$ & 99 \\
\hline To relax & $4.84 \%$ & 44 & $3.90 \%$ & 33 \\
\hline Other & $2.64 \%$ & 24 & $4.02 \%$ & 34 \\
\hline
\end{tabular}

At the end of the survey, participants were provided with the opportunity to give any additional thoughts with a free-text option. Several themes emerged, namely the price of attending, the scheduling of WBBL games, and the use of suburban grounds. Comments on price frequently referred to the food and beverage offerings (particularly at the SCG) and merchandise. As found by Parry et al. (2017), fans were willing to pay these higher prices if the offerings were of greater quality and if they were healthier options. In terms of scheduling, the time gap between the first WBBL game and the following BBL game during the double-header matches at the SCG was identified as a point of frustration for some fans who claimed the interval was often between two and two and a half hours. While it is recognised that there are usually restrictions on start times imposed by broadcasters and 
other stakeholders at sporting matches (Boyle \& Haynes, 2000) this gap results in a variety of issues for attendees, particularly as participants claimed that many of the food and drink outlets were not open before the BBL game started. The SCG is situated in an entertainment complex with a variety of food outlets, but while it is possible to obtain a pass to leave and re-enter the venue, it was suggested by participants that these passes were not well-advertised. One participant also noted an issue with bus services between the nearest train station and the venue, stating that "When the WBBL play at the SCG before a BBL game it would be nice to have buses from Central Station [the nearest train station] direct to the ground in service". It is noteworthy that participants identified discrepancies in the staging of the men's and women's games at the SCG, with a reduction in many of the supporting services that play significant roles in the match-day fan experience.

\section{Discussion}

While noticeable differences have been revealed in the fan experience and the resultant perceptions of value at BBL and WBBL cricket matches, valuable insights into attitudes towards women's professional sport can also be gleaned, as evidenced by the investment and presentation of women's T20 matches. It was found that there were differences in the presentation of BBL and WBBL games at the SCG, which created the perception of more investment in the men's game and greater availability of services that in turn suggest greater professionalisation. The perception of lesser investment in the women's games was created through a combination of closed food and beverage outlets, fewer replays on the screens, fewer activations, and fewer media and entertainment staff at the venue - all of which are expected in commercialised sport offerings. As has been identified previously, women's sport is typically afforded fewer resources than male versions (Fink, 2015), which creates the perception that the 'product' on offer is 'lacklustre' and of lesser value. In terms of media coverage, Musto, et al. (2017) link this practice to gender-bland sexism. Furthermore, there was asymmetrical positioning of the two forms of the game through differences in on-field fan engagement and marketing materials. In terms of the latter, the men's game was portrayed typically using dominant language and as more exciting than the women's, which was marketed as a 'nice day out'. These opposing narrative strategies are reminiscent of Musto et al.'s (2017) findings for sport media and may be a threat to the legitimacy of professionalisation of women's cricket. Interestingly, the players themselves may also be implicit in the establishment of gender-bland sexism. According to our observations, WBBL players were more focussed on the game and less on entertaining and engaging with the crowd, as BBL players were seen to do, which again reduces the degree of excitement and enjoyment within the game. 
These contentions are supported by the fact that fan attendance at WBBL games was free, presented as a bonus match for fans before the men's game commenced. It is, therefore, unsurprising that WBBL matches were valued several dollars lower than BBL equivalents by participants. Before spectators can be expected to place an equal value on women's sport, it is important that those managing the sport (from senior administrators down to venue staff) recognise it as deserving of equal financial investment to the men's game and are cognisant of the impact that subtle differences, such as closed food outlets and a lack of public transport options, can have on spectator perceptions. That such differences continue to exist provides evidence that gender-bland sexism is not solely confined to sports media and can also be found through the presentation of women's professional sport. As noted above, there is a significant gender difference in the financial valuation of WBBL matches with females more likely to purchase tickets, suggesting that there are still barriers to the full acceptance of women's cricket by males, as Russell (2004) claimed over a decade ago. It may be that a sport such as cricket, which is tied to notions of Anglo-Celtic masculinity in Australia (and largely white-dominated at the professional level), continues to exhibit subconscious 'gender marking', with the men's game still seen as the standard against which the women's game is measured. Although there has been an increase in 'interest' in women's professional sports leagues (Nielsen, 2017), work is needed to change the perceptions and consumption patterns of male fans. At the time of data collection, women's professional leagues in Australia were primarily free to attend. It remains to be seen whether attendance numbers will fall if entry prices are on a par with men's games.

Playing games at the SCG (or other high profile venues typically associated with men's Test matches) may add a sense of prestige and legitimacy to women's cricket, but it can appear tokenistic and there are a number of issues associated with WBBL games here. A positive matchday experience makes an event more enjoyable for spectators and increases the likelihood that they will return (Parry et al. 2017). However, a key contributor towards an enjoyable stadium experience is social interaction (Uhrich \& Benkenstein, 2010), with fans enjoying both formal and informal spaces for socialising (Lee et al., 2012). While it could be argued that the large size of the SCG provides ample opportunity for fans to socialise with each other, this ability is negated when a small crowd is dispersed around the large venue and may ultimately contribute negatively towards the creation of the atmosphere. In the words of Lee, et al. (2012, p. 502), "space alone is not sufficient" to increase satisfaction and venues need to facilitate social interactions between fans. Hurstville Oval, with its grass banks around the pitch and open areas inside the perimeter fence, offered more suitable spaces for fans to interact with others in a more convivial and unhurried manner, which has been found to encourage interactions across ethnic and socioeconomic lines (Wise et al., 2018). Furthermore, stadium occupancy rates impact on both the perceived game quality and the visit intention for viewers watching games on 
television - an empty stadium impacting negatively on both factors (Oh, Sung \& Kwon, 2017). The experience for spectators attending venues in person will be positively influenced by stadium occupancy rates as a smaller, fuller stadium will provide a better atmosphere than a near-empty, large venue. Although stadium atmosphere is not a well-understood concept, Uhrich and Benkenstein (2010) identified both the environmental features of the stadium and spectator-induced stimuli as factors in creating a positive atmosphere, which in turn influences decisions to revisit venues. The more welcoming atmosphere associated with WBBL games also offers a point of difference to the intimidatory, hypermasculine atmosphere that frequently pervades men's cricket matches (Rowe, 2017).

It is also possible to make an economic argument for increased investment in WBBL matches. A study into American baseball found that total gross revenues from matches can be increased by spending more on marketing/promotions such as "low value merchandise giveaways, high value merchandise giveaways, group discounts, and fireworks displays" (Cebula, et al., 2013, p.256). Participants in this study, particularly females, identified giveaways as their preferred matchday inclusion to add value to both BBL and WBBL games. As such, greater investment in WBBL games may increase attendances and generate higher revenues for the club. Filling a smaller venue will also drive higher demand for tickets, thus creating the perception of a higher-quality product (Drayer, et al., 2012). To ensure that this perception of higher quality is maintained it would also be necessary to address concerns around the availability and quality of food and beverage offerings.

\section{Conclusion}

This chapter has revealed that there are noticeable differences in the presentation of professional women's cricket matches when compared to men's games, which result in differing fan experiences. Furthermore, both these differences and the venue that games are played at can influence perceptions of quality and value, with men's games valued higher than their female equivalents. The prioritising of men's games renders women's games inferior and serves to marginalise them, which may have implication for the commercial potential and growth of women's cricket. Thus, subtle differences in presentation, as noted above, not only continue to position male sport as more important than women's sport but also provide evidence for the existence of gender-bland sexism in the promotion and presentation of women's sport, in addition to sport media. While this sexism may not be conscious or overt, a lack of investment into women's sport is often justified by a presumed lack of interest in it as Musto et al. (2017) argue. Yet interest in women's sport is evident through the 
increasing number of women's professional leagues and high attendance figures across some sports (Pape, 2020). Further research into the existence of this concept in marketing and promotional materials would provide insights into the structures that shape how audiences are 'encouraged' to think and feel about women's sport and the commercial implications of this marginalisation.

To ensure that women's games are valued, a fee on a par with BBL matches should be introduced for spectators at these games to ensure the 'product' is viewed equally. However, it may be worth setting both of these prices lower than the current BBL rate, as such a move may drive increased attendances at both games and should also result in an increase in sales of merchandise. In addition, if women's games are hosted at smaller venues, a 'better' atmosphere can be created for spectators, enhancing their experience and in turn, creating a demand-driven excitement. Smaller venues also allow the club to create the more intimate, family-friendly atmospheres at games that are associated with women's sport. It can also be argued that such atmospheres should also be recreated in men's games, rather than the current focus on adversarial battles, filled with animosity and the pursuit of dominance over the opposition. A move away from this hyper-masculine idealism would create a more welcoming and inclusive atmosphere.

The need for equality in the marketing and presenting of games is also laid bare by the Covid-19 pandemic. As has been found in other sports, such as association football (Clarkson et al., 2020), resources and finances have been redirected away from the women's professional sport towards men's versions, indicating the priorities of governing bodies of sport. With fans forced to watch sport from home during the pandemic, it is even more important that identified inequalities in the televising of games and gender-bland sexism (Caple, et al., 2011; Lusted \& Fielding-Lloyd, 2017) are addressed so that gender boundaries-hierarchies are made visible and persisting inequalities are addressed (Musto et al., 2017). As with the physical presentation of games, quality and not just quantity does matter.

The fact that males were less likely to purchase tickets for women's matches, were less likely to attend to support women's sport, and valued women's games lower than females did, is an unsettling state of affairs that is indicative of societal views on women's sport. The greatest challenge to those marketing women's cricket is to change the perceptions of the women's game that male fans appear to have so that its commercial potential can be realised. Male fans should be challenged to 'walk the walk, not just talk the talk' when it comes to supporting women's professional sport by purchasing tickets and merchandise. 


\section{Reference list}

Allison, R. (2018). Kicking Center: Gender and the Selling of Women's Professional Soccer. New Brunswick: Rutgers University Press.

Axford, B., \& Huggins, R. (2011). Cricket for people who don't like cricket?: Twenty20 as expression of the cultural and media zeitgeist. Sport in Society, 14(10), 1326-1339. https://doi.org/10.1080/17430437.2011.620375

Boyle, R., \& Haynes, R. (2000). Power Play: Sport, the media, and popular culture. New York: Longman.

Bradley, M. (2013). Defining Fan Engagement. Retrieved from http://bradleyprojects.com/blog.php?id=29

Bruce, T. (2016, 2016/04/01). New Rules for New Times: Sportswomen and Media Representation in the Third Wave. Sex Roles, 74(7), 361-376. https://doi.org/10.1007/s11199-015-0497-6

Caple, H., Greenwood, K., \& Lumby, C. (2011). What League? The Representation of Female Athletes in Australian Television Sports Coverage. Media International Australia, 140 (August), 137-146. https://doi.org/10.1177/1329878X1114000117

Cebula, R. J., Coombs, C. K., Lawson, L., \& Foley, M. (2013). The Impacts of Promotions/Marketing, Scheduling, and Economic Factors on Total Gross Revenues for Minor League Baseball Teams. International Advances in Economic Research, 19(3), 249-257. https://doi.org/10.1007/s11294-013$\underline{9417-0}$

Clarkson, B. G., Culvin, A., Pope, S., \& Parry, K. D. (2020). Covid-19: Reflections on threat and uncertainty for the future of elite women's football in England. Managing Sport and Leisure, 112. https://doi.org/10.1080/23750472.2020.1766377

Creswell, J. W. (2013). Research Design: Qualitative, Quantitative, and Mixed Methods Approaches. London: SAGE Publications.

Coakley, J., Hallinan, C., \& McDonald, B. (2011). Sports in society: sociological issues and controversies (2nd ed.). North Ryde, N.S.W.: McGraw-Hill Australia.

Drayer, J., Shapiro, S. L., \& Seoki, L. (2012). Dynamic Ticket Pricing in Sport: An Agenda for Research and Practice. Sport Marketing Quarterly, 21(3), 184-194. https://doi.org/10.1080/16184742.2015.1129548 
Fielding-Lloyd, B., Woodhouse, D., \& Sequerra, R. (2020, 2020/02/17). 'More than just a game': family and spectacle in marketing the England Women's Super League. Soccer \& Society, 21(2), 166-179. https://doi.org/10.1080/14660970.2018.1541799

Fink, J. (2015). Female athletes, women's sport, and the sport media commercial complex: Have we really "come a long way, baby"? Sport Management Review 18(3), 331-342. https://doi.org/10.1016/i.smr.2014.05.001

Gaskin, L. (2019). AFLW GF crowd 'a significant moment in history', coaches agree. AFL. Retrieved 20th October from https://womens.afl/news/17629/aflw-gf-crowd-a-significant-moment-inhistory-coaches-agree

Hall, J., O'Mahony, B. \& Vieceli, J. (2010). An empirical model of attendance factors at major sporting events. International Journal of Hospitality Management, 29, 328-334.

Jones, I. (1997). Mixing Qualitative and Quantitative Methods in Sports Fan Research. The Qualitative Report, 3(4). Retrieved from http://www.nova.edu/ssss/QR/QR3-4/jones.html

Lee, S., Lee, H. J., Seo, W. J., \& Green, C. (2012). A New Approach to Stadium Experience: The Dynamics of the Sensoryscape, Social Interaction, and Sense of Home. Journal of Sport Management, 26(6), 490-505. http://dx.doi.org/10.1016/j.ijhm.2009.10.011

Lusted, J., \& Fielding-Lloyd, B. (2017). The limited development of English women's recreational cricket: a critique of the liberal "absorption" approach to gender equality. Managing Sport and Leisure, 22(1), 54-69. https://doi.org/10.1080/23750472.2017.1386123

McKay, J., Emmison, M. and Mikosza, J. (2009). Lads, Larrikins and Mates: Hegemonic Masculinities in Australian Beer Advertisements. In Wenner, L. and Jackson, S. (Eds.), Sport, Beer and Gender: Promotional Culture and Contemporary Social Life (pp. 163-180). New York: Peter Lang.

Meier, M. (2015). The value of female sporting role models. Sport in Society, 18(8), 968-982. https://doi.org/10.1080/17430437.2014.997581

Miles, M, A. Huberman, M. and Saldana, J. (2014). Qualitative Data Analysis: A Methods Sourcebook. Thousand Oaks, CA: Sage.

Mooney, A., Hickey, C., Ollis, D., \& Harrison, L. (2019). Howzat! Navigating Gender Disruptions in Australian Young Women's Cricket. Journal of Australian Studies, 43(1), 71-86. https://doi.org/10.1080/14443058.2018.1545139 
Muir, K., Parry, K. D. \& Anderson, E. (2020). Masculinity and Inclusive Rugby in the United Kingdom. In: R. Magrath, J. Cleland, \& E. Anderson (Eds.), The Palgrave Handbook of Masculinity and Sport. (pp. 323-340). Champagne: Palgrave Macmillan.

Musto, M., Cooky, C., \& Messner, M. (2017). "From Fizzle to Sizzle!" Televised Sports News and the Production of Gender-Bland Sexism. Gender \& Society, 31(5), 573-569. https://doi.org/10.1177/0891243217726056

Nielsen (2018, February 20). 10.9 Million Adult Australians Accessed Online Sports Content in January 2018. Nielsen. Retried from http://www.nielsen.com/au/en/press-room/2018/ianuary-2018digital-ratings.html

Osborne, A. C., \& Coombs, D. S. (2013). Performative Sport Fandom: an approach to retheorizing sport fans. Sport in Society, 16(5), 672-681. https://doi.org/10.1080/17430437.2012.753523

Oh, T., Sung, H., \& Kwon, K. D. (2017). Effect of the stadium occupancy rate on perceived game quality and visit intention. International Journal of Sports Marketing and Sponsorship, 18(2), 166-179.

Pape, M. (2020). Rapid rise of women's sport at risk of being halted by Covid-19 outbreak. The Guardian. Retrieved 20th October from https://www.theguardian.com/sport/2020/mar/19/rapid-rise-of-womens-sport-at-risk-ofbeing-halted-by-covid-19-outbreak

Parry, K. D. (2012). Game of two passions: a football fan's autoethnography. Qualitative Research Journal, 12(2), 238 - 250. https://doi.org/10.1108/14439881211248374

Parry, K. D., Hall, T., \& Baxter, A. (2017). Who ate all the pies? The importance of food in the Australian sporting experience. Sport in Society, 20(2), 202-218. https://doi.org/10.1080/17430437.2016.1173916

Parry, K. D., Jones, I., \& Wann, D. L. (2014). An Examination of Sport Fandom in the United Kingdom: A Comparative Analysis of Fan Behaviors, Socialization Processes, and Team Identification. Journal of Sport Behavior, 37(3), 251-267. https://doi.org/10.1177/1012690210380582

Parry, K. D., Rowe, D., George, E. S., \& Hall, T. J. (2018). Healthy sport consumption: Moving away from pies and beer. In D. Parnell \& P. Krustrup (Eds.), Sport and Health: Exploring the Current State of Play (pp. 219-237). London: Routledge. 
Parry, M., \& Malcolm, D. (2004). England's Barmy Army: Commercialization, Masculinity and Nationalism. International Review for the Sociology of Sport, 39(1), 75-94. https://doi.org/10.1177/1012690204040524

Phonthanukitithaworn, C. \& Sellitto, C. (2018). Perceptions of service quality at football stadiums: influence on fans' intention to attend future games. Managing Sport and Leisure, 23(3), 204224. https://doi.org/10.1080/23750472.2018.1544850

Richards, J., Parry, K. D., \& Gill, F. (2020). "The guys love it when chicks ask for help": an exploration of female rugby league fans. Sport in Society, 1-18. https://doi.org/10.1080/17430437.2020.1809380

Rowe, D. (2013 December 10). The Ashes: Australian masculinity reborn amid English tumult. The Conversation. Retrieved from https://theconversation.com/the-ashes-australian-masculinityreborn-amid-english-tumult-21265.

Russell, K. (2004). On Versus Off the Pitch: The Transiency of Body Satisfaction Among Female Rugby Players, Cricketers, and Netballers. Sex Roles, 51(9-10), 561-574. https://doi.org/10.1155/2018/6835751

Shaw, S. \& Amis, J. (2001). Image and Investment: Sponsorship and Women's Sport. Journal of Sport Management, 15(3) 219-246. https://doi.org/10.1123/jsm.15.3.219

Stronach, M. and Adair, D. (2009). "'Brave new world' or 'sticky wicket'? Women, management and organizational power in Cricket Australia." Sport in Society, 12(7): 910-932. https://doi.org/10.1080/17430430903053174

Sydney Sixers. (2018). Our Club. Retrieved from https://www.sydneysixers.com.au/our-club Tailgate Sports Marketing (2016, November 21). How to Increase Attendance of Female Fans with Fan Engagement. Retrieved from https://www.tailgatingsportsmarketing.com/blog/increaseattendance-female-fans-fan-engagement-2/

Trail, G.T. and Kim, Y.K. (2011). Factors influencing spectator sports consumption: NCAA women's college basketball. International Journal of Sports Marketing and Sponsorship, 13(1), 55-77. https://10.1108/IJSMS-13-01-2011-B006

Uhrich, S., \& Benkenstein, M. (2010). Sport Stadium Atmosphere: Formative and Reflective Indicators for Operationalizing the Construct. Journal of Sport Management, 24(2), 211-237. https://doi.org/10.1123/jsm.24.2.211 
Wann, D. \& Waddill, P. (2003). Predicting Sport Fan Motivation Using Anatomical Sex and Gender Role Orientation. North American Journal of Psychology, 5(3), 485-498.

Wade, M. (2019). Tactics of the 'Ugly Australian': Morality, masculinity, nationalism and governance amid a cheating controversy in sport. Journal of Sociology, 55(3), 528-550. https://doi.org/10.1177/1440783319833466

Wedgwood, N. (1997). 'Spewin', mate!' A day at the cricket [Observations of the crowd at a cricket match between Australia and Pakistan.]. Social Alternatives, 16(3), 26-30. Availability: https://search.informit.com.au/documentSummary;dn=980100191;res=IELAPA

Wise, A., Parry, K. D., Aquino, K., Neal, S., \& Velayutham, S. (2018). Pushing casual sport to the margins threatens cities' social cohesion. Retrieved from https://theconversation.com/pushingcasual-sport-to-the-margins-threatens-cities-social-cohesion-92352 